\title{
Antagonism of different species of Lactobacillus spp. against phytobacteria
}

\author{
Antagonismo de diferentes espécies de Lactobacillus spp. frente a fitobactérias \\ Antagonismo de distintas especies de Lactobacillus spp. contra fitobacterias
}

Received: 01/14/2022 | Reviewed: 01/22/2022 | Accept: 01/23/2022 | Published: 01/25/2022

\author{
Rodolfo Sodré Tavares \\ ORCID: https://orcid.org/0000-0003-1594-3741 \\ Federal University of Goiás, Brazil \\ E-mail: free_flying_@hotmail.com \\ Paulo Alex Neves da Silva \\ ORCID: https://orcid.org/0000-0002-0675-9873 \\ Federal University of Goiás, Brazil \\ F-mail: disponnivel@hotmail.com \\ Ludmila Batista Machado \\ ORCID: https://orcid.org/0000-0001-8479-5119 \\ Catholic University of Goiás, Brazil \\ E-mail: milabatistam@gmail.com \\ Abadia dos Reis Nascimento \\ ORCID: https://orcid.org/0000-0003-3952-5878 \\ Federal University of Goiás, Brazil \\ E-mail: abadiadosreis@ufg.br \\ Lilian Carla Carneiro \\ ORCID: https://orcid.org/0000-0003-4067-1506 \\ Federal University of Goiás, Brazil \\ E-mail: liliancarla@ufg.br \\ José Daniel Gonçalves Vieira \\ ORCID: https://orcid.org/0000-0001-5434-4915 \\ Federal University of Goiás, Brazil \\ E-mail: jvieira@ufg.br
}

\begin{abstract}
Tomato (Solanum lycopersicum L.) is one of the most important and most cultivated vegetables in the world, having a market for derivative products with high commercial appeal. The inoculation of probiotic bacteria can act in the prevention of diseases such as bacterial spots, bacterial wilt, soft rot, among others, in addition to reducing the use of pesticides and antibiotics, helping to mitigate the impact on humans and environmental health. Part of the samples used for the isolation of LAB was collected from leaves of healthy tomato plants at the Escola de Agronomia (EA) of the Federal University of Goiás (UFG) and another part was obtained from a starter culture from the local market. Two methods of antagonism were used, the diffusion test in a liquid medium and the test in a solid medium. Of the 13 strains tested in this study, 10 showed activity against different phytobacteria, the antagonistic activity test in liquid medium was better compared to a solid medium, broad-spectrum antimicrobial action, and an inhibition halo of up to $22 \mathrm{~mm}$ of diameter from a strain obtained from a starter culture. Thus, this work demonstrates the antimicrobial activity of LAB strains tested in vitro against different phytobacteria.
\end{abstract}

Keywords: Bioprospecting; Biological control; Lactobacillus spp; Solanum lycopersicum; Xanthomonas spp.

\section{Resumo}

O tomateiro (Solanum lycopersicum L.) é uma das hortaliças mais importantes e mais cultivadas do mundo, possuindo um mercado de produtos derivados com alto apelo comercial. A inoculação de bactérias probióticas pode atuar na prevenção de doenças como, mancha bacteriana, murcha bacteriana, podridão mole, entre outras, além de diminuir a utilização de pesticidas e antibióticos, ajudando a mitigar o impacto à saúde humana e ambiental. Parte das amostras utilizadas para o isolamento de BAL foram coletadas a partir de folhas de tomateiros sadios na Escola de Agronomia (EA) da Universidade Federal de Goiás (UFG) e outra parte foi obtida de cultura starter a partir do mercado local. Dois métodos de antagonismo foram utilizados, o teste de difusão em meio líquido e o teste em meio sólido. Das 13 cepas testadas neste estudo, 10 apresentaram atividade contra diferentes fitobactérias, o teste de atividade antagônica em meio líquido mostrou-se melhor em comparação ao meio sólido, também foi encontrada ação antimicrobiana de amplo espectro e um halo de inibição de até $22 \mathrm{~mm}$ de diâmetro proveniente de uma cepa obtida a partir de cultura starter. Desta forma este trabalho demonstra a atividade antimicrobiana de cepas de BAL testadas in vitro contra diferentes fitobactérias.

Palavras-chave: Bioprospecção; Controle biológico; Lactobacillus spp; Solanum lycopersicum; Xanthomonas spp. 


\section{Resumen}

El tomate (Solanum lycopersicum L.) es una de las hortalizas más importantes y cultivadas en el mundo, teniendo un mercado de productos derivados con alto atractivo comercial. La inoculación de bacterias probióticas puede actuar en la prevención de enfermedades como la mancha bacteriana, marchitez bacteriana, pudrición blanda, entre otras, además puede reducir el uso de pesticidas y antibióticos, ayudando a mitigar el impacto en la salud humana y ambiental. Parte de las muestras utilizadas para el aislamiento de BAL se recogieron de hojas de plantas de tomate sanas en la Escuela de Agronomia (EA) de la Universidad Federal de Goiás (UFG) y otra parte se obtuvo de un cultivo iniciador del mercado local. Se utilizaron dos métodos de antagonismo, la prueba de difusión en medio líquido y la prueba en medio sólido. De las 13 cepas probadas en este estudio, 10 mostraron actividad contra distintas fitobacterias, la prueba de actividad antagónica en medio líquido fue mejor en comparación con el medio sólido, acción antimicrobiana de amplio espectro y un halo de inhibición de hasta $22 \mathrm{~mm}$ de diámetro a partir de una cepa obtenida de una cultura iniciadora. Por lo tanto, este trabajo demuestra la actividad antimicrobiana de las cepas de LAB probadas in vitro contra diferentes fitobacterias.

Palabras clave: Bioprospección; Control biológico; Lactobacillus spp; Solanum lycopersicum; Xanthomonas spp.

\section{Introduction}

Tomato (Solanum lycopersicum L.) is one of the most important and most cultivated vegetables in the world, having a market of by-products with high commercial appeal both for industrialized products such as soups, sauces, purees and ketchup, as well as a wide range of cultivars intended in natura consumption, being part of the daily diet of a large part of the world population (Wang et al., 2018). It is also of great nutritional importance due to the presence of several compounds beneficial to health, such as ascorbic acid (Vitamin C), flavonoids, carotenoids ( $\beta$-carotenes), folic acid, carbohydrates, dietary fiber and lycopene (Khanna et al., 2019).

The commercialization of tomato and its derivatives exerts a significant impact on the trade balance of several countries (FAO, 2021). Because it is vulnerable to several biotic and abiotic factors such as attack by parasites, weeds, high humidity and temperature, which favors the attack of various phytobacteria (Silva et al., 2006), such as Xanthomonas pathovars, Clavibacter michiganensis subsp. michiganensis, Pectobacterium carotovorum and Pseudomonas corrugata, leading to the appearance of bacterial spot, seed infection and soft rot, respectively (Zaluga et al., 2013; Teper et al., 2018).

Due to the increase in the world population and consequently a growing demand for various foods, including tomatoes and their derivatives, the use of pesticides and antibiotics are among the main strategies to fight their diseases, including those caused by phytobacteria (Wang et al., 2018). However, it is worth noting that the use of pesticides banned from the market and with a high degree of toxicity for humans and the environment are still being marketed in many countries, as well as the use of antibiotics on a large scale inducing the development of resistant bacterial isolates making the use of probiotics as a form of biological control to become a good alternative (Itako et al., 2015).

Thus, the objectives of this work were to isolate and test strains of lactic acid bacteria (LAB) against different phytobacteria applying the diffusion test methodology in liquid and solid media.

\section{Material and Methods}

\subsection{Place of execution of the experiments}

The experiments were carried out at the Laboratory of Environmental Microbiology and Biotechnology (LAMAB) of the Tropical Pathology and Public Health Institute (IPTSP) of the Federal University of Goiás (UFG). The microorganisms used in this research are part of the bacteriotheca belonging to laboratory, being preserved in $20 \%$ glycerol (m/v) at a temperature of $-20^{\circ} \mathrm{C}$. 


\subsection{Isolation of lactic acid bacteria (LAB) present in healthy tomato plants from the School of Agronomy of the Federal} University of Goiás

To isolate the LABs, Man, Rogosa and Sharpe agar (MRS) and MRS broth with pH adjustment to $6.5 \pm 0.2$ were used, this medium was chosen because it has a considerable acceptance as a medium of global use for isolation of these microorganisms in particular due to its high efficiency and ability to sustain a wide range of LAB. For the solid medium, $17 \mathrm{~g}$ of Agar were used for each 1 liter of water (Carr et al., 2002).

Samples of healthy tomato plants were collected from the School of Agronomy of Federal University of Goiás and placed in sterile plastic bags and taken to laboratory. In the laboratory, the vegetables were introduced in $300 \mathrm{~mL}$ Erlenmeyers containing a saline solution $(\mathrm{NaCl} 0.85 \% \mathrm{~m} / \mathrm{v})$ and incubated at $135 \mathrm{rpm} / 30{ }^{\circ} \mathrm{C}$ in a shaker for two hours. After this time 1.0 $\mathrm{mL}$ aliquots were removed and diluted to $10^{-6}$ in screw tubes containing $9.0 \mathrm{~mL}$ of a new saline solution $(\mathrm{NaCl} 0.85 \% \mathrm{~m} / \mathrm{v})$. $100 \mu \mathrm{L}$ of the dilutions were removed and inoculated in Petri dishes containing MRS Agar and screw tubes containing MRS broth and incubated at $37^{\circ} \mathrm{C}$ until colonies developed on the plates and turbidity in the tubes. The colonies were removed with the aid of an autoclaved toothpick and inoculated in Petri dishes containing MRS Agar and incubated as described above.

The material grown in the tubes was inoculated into Petri dishes containing MRS Agar and incubated as described above. Grown colonies were isolated and replicated as described. Bacteria grown on the plates by the two processes were purified by repeating the above procedure for $3 \mathrm{x}$ until obtaining a visually axenic culture.

The isolates were kept in $20 \%$ glycerol $(\mathrm{m} / \mathrm{v})$ in $2.0 \mathrm{~mL}$ Eppendorfs-type tubes in a freezer at $-20{ }^{\circ} \mathrm{C}(\mathrm{Costa}$ et al., 2009) until the moment of use.

\subsection{Isolation of LAB from starter culture}

For the isolation of $\mathrm{LAB}$, a culture of $\mathrm{LAB}$ obtained from a local commerce manipulation pharmacy was used. In the laboratory, only a portion of the total contents of the capsules were introduced into a $50 \mathrm{~mL}$ Erlenmeyer flask containing autoclaved saline $(0.85 \% \mathrm{~m} / \mathrm{v} \mathrm{NaCl})$, then incubated at $150 \mathrm{rpm} / 37^{\circ} \mathrm{C}$ in a shaker for 2 hours. After this time, $1.0 \mathrm{~mL}$ aliquots were removed and diluted to $10^{-8}$ in screw tubes containing $9.0 \mathrm{~mL}$ of a new saline solution $(\mathrm{NaCl} 0.85 \% \mathrm{~m} / \mathrm{v})$. $100 \mu \mathrm{L}$ of the dilutions were removed and inoculated in Petri dishes containing MRS Agar and screw tubes containing MRS broth and incubated at $37^{\circ} \mathrm{C}$ until colonies developed on the plates and turbidity in the tubes. The colonies were removed with the aid of an autoclaved toothpick and inoculated in Petri dishes containing MRS Agar and incubated as described above. Bacteria grown by both methods were purified by repeating the above procedure for $3 \mathrm{x}$ until obtaining a visually axenic culture. The form of storage took place as described in the previous step.

\subsection{Isolation of Xanthomonas spp. present in sick tomatoes}

To isolate Xanthomonas bacteria, the semi-selective medium NYDAM (NYDA+ampicillin) with the following composition was used; ( $3 \mathrm{~g}$ meat extract, $5 \mathrm{~g}$ peptone, $10 \mathrm{~g}$ glucose, $5 \mathrm{~g}$ yeast extract, $18 \mathrm{~g}$ agar, ampicillin $100 \mathrm{mg}$ L-1 distilled water). The isolation of different Xanthomonas pathovars can occur from various infected plant tissues, especially without the interference of saprophytes, thus helping to identify the microorganism. The observable growth occurs after $24 / 48$ hours, showing small and yellowish colonies, thus being very useful for the isolation and growth of Xanthomonas spp. because, according to Peixoto (2006), some semi-selective media can be sensitive to molecular techniques such as the polymerase chain reaction (PCR) and immunological techniques, with the advantage of being easier to be identified and less expensive. Samples from diseased tomato plants were collected, placed in sterile plastic bags and taken to the laboratory. 
In the laboratory, the leaves were separated into portions with the help of a disposable scalpel blade (MAXICOR), being introduced in a $250 \mathrm{~mL}$ Erlenmeyer, containing saline solution $(\mathrm{NaCl} 0.85 \% \mathrm{~m} / \mathrm{v})$ and incubated at $130 \mathrm{rpm} / 29^{\circ} \mathrm{C}$ in a shaker for two hours. After this time $1.0 \mathrm{~mL}$ aliquots were removed and diluted to $10^{-6}$ in screw tubes containing $9.0 \mathrm{~mL}$ of a new saline solution $(\mathrm{NaCl} 0.85 \% \mathrm{~m} / \mathrm{v}) .100 \mu \mathrm{L}$ of the dilutions were removed and inoculated in Petri dishes containing NYDAM medium and incubated at $29^{\circ} \mathrm{C}$ until colony development.

After growing, the colonies were removed with the aid of an autoclaved toothpick and inoculated in Petri dishes containing NYDAM medium and incubated as described above. Grown colonies were isolated and replicated as described. The bacteria grown were purified by repeating the above procedure for $3 \mathrm{x}$ until obtaining a visually axenic culture.

The isolates were kept in $20 \%$ glycerol $(\mathrm{m} / \mathrm{v})$ in $2.0 \mathrm{~mL}$ Eppendorfs-type tubes in a freezer at $-20{ }^{\circ} \mathrm{C}$ (Costa et al., 2009) until the moment of use.

\subsection{Preliminary characterization of LAB strains}

On macroscopic observation, white, opaque colonies and well-defined borders were noted, with rapid growth in MRS medium for $24 / \mathrm{h}$. During microscopy, microorganisms with bacilliform, gram-positive and non-spore-forming morphology were observed. Negative for the Catalase test performed on a microscope slide previously decontaminated with $70 \%$ alcohol. Presenting growth with optimal growth temperature ranging from 30 to $37^{\circ} \mathrm{C}$.

\subsection{Morphotintorial identification test}

An axenic culture smear was prepared, using a clean and degreased slide, applying the Gram stain technique. The preparation of the smear took place in the laminar flow hood, thus minimizing possible interference from the environment, protecting the samples handled inside it (Modesto et al., 2016). First, a $10 \mu \mathrm{L}$ aliquot of autoclaved saline $(0.85 \% \mathrm{~m} / \mathrm{v} \mathrm{NaCl})$ was inoculated in the center of the slide, then an isolated colony from the MRS medium was captured and, with the help of an autoclaved toothpick, the material was combined to form a uniform smear.

After this procedure, the material was fixed by heat, quickly passing the lower part of the blade through the bunsen nozzle for $3 \mathrm{x}$. Next, the set for Gram staining was used. The slide was covered with Gentian Violet dye (GRAM) in order to cover the entire smear, keeping it for 1 minute. Then, the slide was washed with distilled water. The next step was to cover the smear with Lugol weak (GRAM) preserving it for another 1 minute, then the slide was washed again with distilled water, then decolorized with the Bleaching Solution (GRAM). In the next step, after repeating the washing process as described above, the last dye, Fenicated Fuchsin (Gram) was added, waiting for 30 seconds, the washing process was repeated and the slide was dried at room temperature. The smear was taken to the microscope where, first, it was observed in a 10x objective to examine the coloration then, in immersion using mineral oil in a 100x objective.

\subsection{Test of antagonistic activity in liquid medium}

For this test, the LAB strains were grown in tubes containing $5 \mathrm{~mL}$ of MRS broth at $37^{\circ} \mathrm{C}$ overnight, after which time the culture was centrifuged at $5000 \mathrm{~g}$ for 15 minutes at $4{ }^{\circ} \mathrm{C}$. A $2 \mathrm{~mL}$ portion of the supernatant was transferred to previously autoclaved and identified Eppendorfs tubes, the procedure was repeated for all bacteria as described above. The indicator strains were standardized for turbidity in tube No. 0,5 on the McFarland scale $\left(1,5 \times 10^{8}\right)$ and then inoculated in a Petri dish containing Müeller-Hinton agar. The indicator strains used were Xanthomonas pathogenic for pepper (X-PIM), Xanthomonas spp. pathogenic for Sugarcane (XTC), two strains of Xanthomonas spp. isolated from School of Agronomy of Federal 
University of Goiás (XT1-TX2), Clavibacter michiganensis subsp. michiganensis (CMM), Pectobacterium carotovorum (PC) and Pseudomonas corrugata (PCOR).

After this procedure, $5.0 \mathrm{~mm}$ diameter wells were made with the help of a previously autoclaved tool, $100 \mu \mathrm{L}$ of the supernatant were inoculated and incubated for 24 hours at $37{ }^{\circ} \mathrm{C}$. As a negative control, an aliquot of $100 \mu \mathrm{L}$ of growth-free MRS broth was used. After this time the zone of inhibition was determined by measuring the halos as described by (Prabhurajeshwar; Chandrakanth, 2017), with modifications.

\subsection{Test of antagonistic activity in solid medium - "plugs" technique}

Previously isolated LAB were cultivated in MRS agar for 2 days at $37{ }^{\circ} \mathrm{C}$ until confluent growth was obtained. Soon after this period, $1 \mathrm{~mL}$ of chloroform was added over the inner lid of the poured Petri dish, after 10 minutes and complete evaporation of the chloroform, cylinders of approximately $7.0 \mathrm{~mm}$ in diameter (plugs) were cut with the help of a special instrument previously autoclaved, then they were inoculated on a petri dish containing Müeller-Hinton agar previously inoculated with the phytobacteria, standardized for the turbidity of tube No. 0,5 on the McFarland scale $\left(1,5 \times 10^{8}\right)$.

The procedure was repeated for all bacteria as described above. Plates were incubated for 24 hours at $37{ }^{\circ} \mathrm{C}$. After this time the zone of inhibition was determined by measuring the halos (Biagi \& Azevedo, 1992). As a negative control, a growthfree MRS agar plug was used.

\section{Results and Discussion}

The use of probiotics, especially LAB, as a form of biological control against phytopathogens has been gaining more space due to their potential (Forhad et al., 2015). Some strains are considered safe by both the US Food and Drug Administration (FDA) and the European Food Safety Authority (EFSA) in Europe (Fang et al., 2020). Probiotics are defined as live microorganisms, which when administered in certain amounts can provide benefits to the host (Mohamed et al., 2016). Among probiotics, LAB bacteria are widely used in the most diverse fields, such as human medicine, veterinary medicine, food preservation, plant improvement and disease prevention as a form of biological control (Limanska et al., 2015).

In this study it was observed that most Lactobacillus spp. showed some degree of activity against the strains of phytobacteria tested (Table 1), only the phytopathogen XT2 isolated from the School of Agronomy of the Federal University of Goiás, was resistant to all Lactobacillus spp. 
Table 1 - Antagonistic activity of different species of Lactobacillus spp. grown in MRS broth and agar against different phytopathogenic bacteria isolates. 1 Probiotic microorganisms belonging to the laboratory. 2. Phytopathogenic bacteria belonging to the laboratory - CMM. Clavibacter michiganensis subsp. michiganensis. PC. Pectobacterium carotovorum. PCOR. Pseudomonas corrugata. XTC. Cane Xanthomonas. X-PIM. Pepper Xanthomonas. 3. Isolated microorganism from the School of Agronomy of the Federal University of Goiás-XT1. Xanthomonas tomato1. * Average of 3 repetitions.

\begin{tabular}{|c|c|c|c|c|c|c|c|c|c|c|c|c|}
\hline & \multicolumn{12}{|c|}{ inhibition halo (Ø mm)* } \\
\hline \multirow{3}{*}{ Indicator bacteria } & \multirow{2}{*}{\multicolumn{2}{|c|}{$\mathrm{CMM}^{2}$}} & \multirow{2}{*}{\multicolumn{2}{|c|}{$\mathbf{P C}^{2}$}} & \multirow{2}{*}{\multicolumn{2}{|c|}{ PCOR $^{2}$}} & \multirow{2}{*}{\multicolumn{2}{|c|}{$\mathrm{XTC}^{2}$}} & \multirow{2}{*}{\multicolumn{2}{|c|}{ X-PIM² }} & \multirow{2}{*}{\multicolumn{2}{|c|}{$\mathbf{X T 1}^{3}$}} \\
\hline & & & & & & & & & & & & \\
\hline & Liquid & Solid & Liquid & Solid & Liquid & Solid & Liquid & Solid & Liquid & Solid & Liquid & Solid \\
\hline L. Breve ${ }^{1}$ & - & 9 & 20 & 16 & 9 & 7 & 12 & 9 & 11 & 9 & 11 & 15 \\
\hline $\begin{array}{l}\text { L. delbrueckii } \\
\text { subsp. bulgaricus } 1\end{array}$ & - & - & - & - & - & - & 15 & 10 & - & - & - & 7 \\
\hline L. delbrueckii ${ }^{1}$ & 9 & 7 & 20 & 16 & 9 & 7 & 11 & 9 & 8 & 7 & - & 14 \\
\hline L. gasseri $^{1}$ & - & - & 21 & 15 & 7 & 7 & 14 & 8 & 9 & 9 & - & 14 \\
\hline L. helveticus ${ }^{1}$ & 10 & 9 & - & - & 14 & 9 & 14 & 9 & 15 & 8 & - & - \\
\hline L. johnsonii ${ }^{1}$ & 10 & 8 & 21 & 18 & 10 & 9 & 12 & 8 & 10 & 7 & 18 & 16 \\
\hline L. plantarum ${ }^{1}$ & 9 & 7 & 21 & 15 & 10 & 9 & 11 & 9 & 9 & 7 & - & 14 \\
\hline L. rhamnosus ${ }^{1}$ & 7 & 7 & 8 & 7 & 9 & 8 & 15 & 11 & 8 & - & - & 16 \\
\hline L. sporogenes ${ }^{1}$ & 8 & 7 & 22 & 16 & 8 & 7 & 9 & 7 & 7 & - & 16 & 11 \\
\hline S. thermophilus ${ }^{1}$ & - & - & - & - & - & - & 11 & 7 & - & - & - & 7 \\
\hline
\end{tabular}

Source: The authors.

Of the 13 LAB analyzed in this study (12 Lactobacillus and 1 Streptococcus thermophilus) had the potential to inhibit almost all tested phytopathogens, including one gram-positive microorganisms, suggesting that the spectrum of action is not restricted to gram-negative microorganisms. These results suggest the production of molecules with antimicrobial capacity, whether new substances or those already mentioned in the literature (Rodrigues, 2009).

The production of substances with inhibitory potential by LAB can be explained in part by products of metabolism such as organic acids, which are one of the components resulting from the fermentation process of these bacteria, these acids act to reduce the $\mathrm{pH}$, thus acidifying the environment, where lactic acid and acetic acid can also act directly as an antagonistic substance against other microorganisms, interacting directly, acidifying the intracellular environment and causing apoptosis, in addition to the formation of hydrogen peroxide can also be involved in antagonism (Gänzle et al., 2000).

Another class of molecules that can help explain this effect are bacteriocins, these protein complexes synthesized in ribosomes, which feature as a characteristic being thermostable and also resistant to proteases, are usually small molecules ranging from 6 to 8 kilodaltons $(\mathrm{kDa})$ of molecular weight. There is also an intricate system of formation and secretion of this molecule, which depends on the activation of genes and other protein complexes that allow the secretion of bacteriocin without 
the bacterial cell producing being the target of its action, as these antimicrobial compounds act on the cell membrane of the cell target, inducing apoptosis by osmotic lysis (Pandey et al., 2013).

Of the isolates presented in this study, the Lactobacillus sporogenes strain presented the greatest inhibition zone, followed by L. breve, L. delbrueckii, L. gasseri, L. johnsonii and L. plantarum. The highest antagonistic activity was against a strain of $P$. carotovorum, in the liquid medium antagonism test, activity was also obtained against a Xanthomonas pathovar isolated from the School of Agronomy of the Federal University of Goiás (XT1), suggesting the presence of a biomolecule with promising antimicrobial activity ( Figure 1).

Figure 1. Antagonistic activity test in liquid medium. (1) L. rhamnosus. (2) L. delbrueckii. (3) L. plantarum. (4) L. sporogenes. (5) L. johnsonii. (6) L. soon. (7) L. gasseri. (8) FT1. (9) L. helveticus. (10) ST1. (11) FT2. (12) L. bulgaricus. subsp. debrueckii. (13) S. thermophilus. (14) control. (15) indicator bacteria. (A) P. carotovorum. (B) Xanthomonas spp. tomato1.

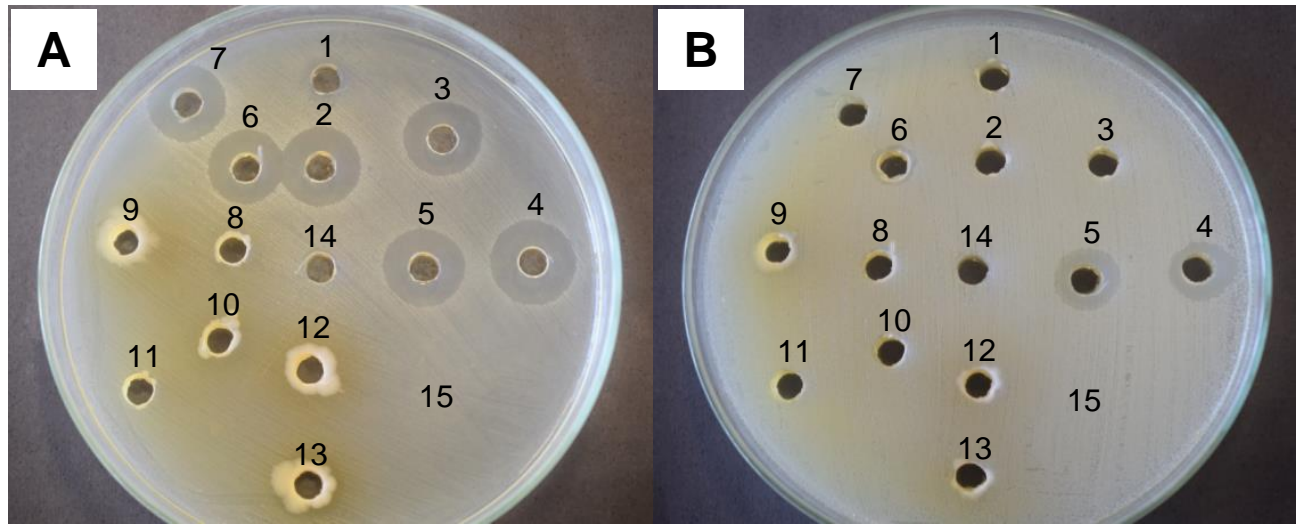

Source: The authors.

These data are in agreement with those of Limanska et al. (2015) and Daranas et al. (2018), where the use of LAB strains is reported as a form of biological control against different types of phytobacteria, including Xanthomonas pathovars. Various species of Xanthomonas spp. are considered pathogenic for several crops, including grapes, pomegranates, mangoes, peppers, sugarcane, tomatoes, among others (Midha \& Patil, 2014), in this sense, the screening for strains that express activity against these phytobacteria is of big interest.

In the diffusion test using the "plugs" technique, there was a smaller zone of inhibition compared to the technique using the MRS broth, as can be seen in (Figure 2). 
Figure 2. Antagonistic activity test in solid medium "plugs" technique. (1) L. rhamnosus. (2) L. delbrueckii. (3) L. plantarum. (4) L. sporogenes. (5) L. johnsonii. (6) L. breve. (7) L. gasseri. (8) FT1. (9) L. helveticus. (10) ST1. (11) FT2. (12) L. bulgaricus. subsp. delbrueckii. (13) S. thermophilus. (14) control. (15) indicator bacteria. (A) P. carotovorum. (B) Xanthomonas spp. tomato1.

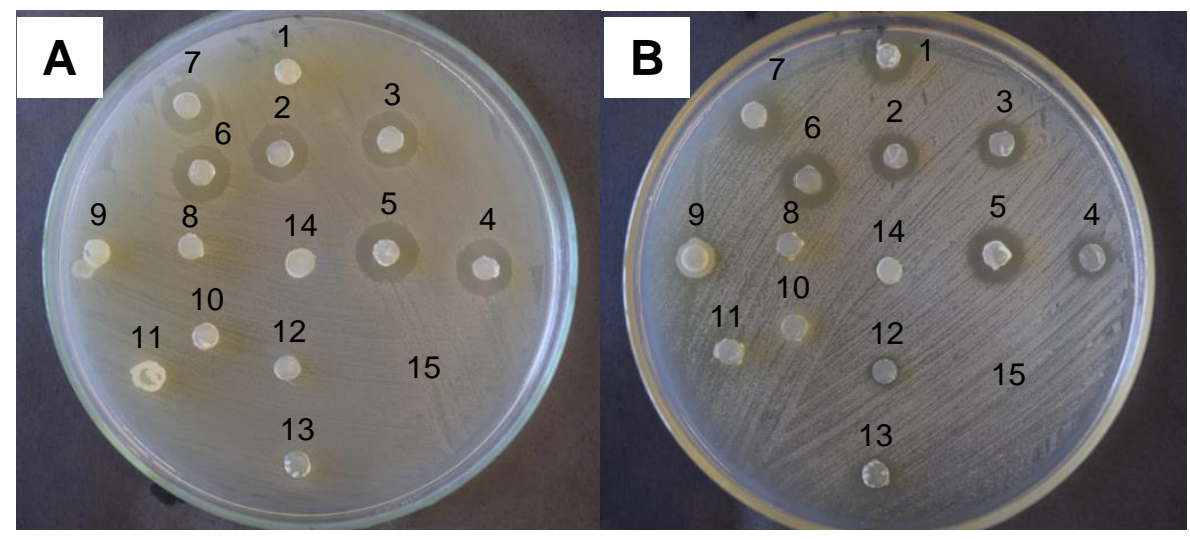

Source: The authors.

As a result, the diffusion method in liquid medium proved to be better compared to the solid medium "plugs", this can be explained by the sum of the set of all metabolites present in the medium acting synergistically as; lactic acid, acetic acid, hydrogen peroxide and bacteriocin. On the other hand, in the solid medium, a longer incubation time compared to the liquid medium may have enhanced the conditions for the growth and activity of other strains, although with the formation of a smaller zone of inhibition, suggesting the activity of only the bacteriocin (Biagi \& Azevedo, 1992; Çadirci \& Çitak, 2005).

The LAB strains isolated from the School of Agronomy of the Federal University of Goiás did not show activity against the microorganisms tested in this study. The only microorganism resistant to all isolates in this work was XT2, indicating a possible resistance to the LAB strains screened by us. However, it is necessary to emphasize that the in vitro experiments may not portray natural conditions in their entirety, this may help to explain the divergent activity patterns between the liquid, solid or, in certain cases, their absence (Rodrigues, 2009).

\section{Conclusion}

The strains obtained from starter culture obtained in the region's trade were the most active, out of a total of 13 strains tested in this study, 10 showed activity against different phytobacteria, among these, seven expressed the best antimicrobial activities with a zone of inhibition of up to $22 \mathrm{~mm}$ in diameter (L. sporogenes) and, among this last group, L. johnsonii, L. breve and L. plantarum showed the highest number of activity, respectively, with only one strain resistant to all tested LAB.

The antagonistic activity test in liquid medium was better compared to solid medium. Broad spectrum antimicrobial action was found, both gram-positive and gram-negative phytopathogens were inhibited. The LAB strains presented in this study proved to be promising, with great potential for biological control and with possible implementation in the practice of tomato disease control.

Due to the potential of strains tested in vitro in the present study, it is essential to apply in vivo tests to evaluate the use of the tested isolates for the antagonistic activity. Brazil is one of the largest tomato producers in the world, therefore, research on new therapeutic approaches and screening for strains of microorganisms of biotechnological interest, aiming at the biological control of tomato phytobacteria, can help to direct the country to new control strategies, thus helping to mitigate the 
Research, Society and Development, v. 11, n. 2, e28011225760, 2022

(CC BY 4.0) | ISSN 2525-3409 | DOI: http://dx.doi.org/10.33448/rsd-v11i2.25760

negative impact of chemical waste on human, animal, and environmental health.

\section{Acknowledgments}

The authors thank the Brazilian Federal Agency for Support and Evaluation of Graduate Education (CAPES) for the scholarship awarded to the first author. And the School of Agronomy of the Federal University of Goiás for the samples collected.

\section{References}

Biagi, C. M. R., \& Azevedo, J. L. (1992). Detecção de bacteriocinas produzidas por bactérias fitopatogênicas dos gêneros Erwinia, Pseudomonas e Xanthomonas. Scientia Agricola, 49, 1-8.

Çadirci, B. H., \& Çitak, S. (2005). A Comparison of Two Methods Used for Measuring Antagonistic Activity of Lactic Acid Bacteria. Pakistan Journal of Nutrition, 4, 237-241.

Carr, J. F., Chill, D., \& Maida, N. (2002). The Lactic Acid Bacteria: A Literature Survey, Critical Reviews in Microbiology, 28, $281-370$.

Costa, C. E., Teixeira, S. F. M., Dantas, M. V. T., Melo, P. S. V., Araújo, C. A. S., \& Rolim, N. B. (2009). Microbiological samples storage and preservation principles, Ciência Animal, 19, 111-112.

Daranas, N., Badosa, E., Francés, J., Montesinos, E., \& Bonaterra, A. (2018). Enhancing water stress tolerance improves fitness in biological control strains of Lactobacillus plantarum in plant environments. PLOS ONE, 13, 1-21.

Fang, X., Duan, Q., Wang, Z., Li, F., Du, J., Ke, W., Liu, D., Beier, R. C., Guo, X., \& Zhang, Y. (2020). Products of Lactobacillus delbrueckii subsp. bulgaricus Strain F17 and Leuconostoc lactis Strain H52 Are Biopreservatives for Improving Postharvest Quality of 'Red Globe' Grapes, Microorganisms, 8, $1-16$.

FAO-FAOSTAT (2021). Food and Agriculture Organization of the United Nations. Retrieved Jun 4, 2021, http://faostat.fao.org/.

Forhad, M. H., Rahman, S. M. K., Rahman, S., Saikot, F. K., \& Biswas, K. C. (2015). Probiotic Properties Analysis of Isolated Lactic Acid Bacteria from Buffalo Milk, Archives of Clinical Microbiology, 7, 1-6.

Gänzle, M. G., Höltzele, A., Walter, J., Jung, G., \& Hammes, W. P. (2000). Characterization of Reutericyclin Produced by Lactobacillus reuteri LTH2584. Applied and Environmental Microbiology, 66, 4325-4333.

Gordon, S. (2008). Elie Metchnikoff: Father of natural immunity. European Journal of Immunology, 38, 3257-3264.

IBGE (2021). Sistema Brasileiro de Geografia e Estatística. Retrieved Jun 4, 2021, https://sidra.ibge.gov.br/tabela/1612.

Itako, A. T., Júnior, J. B. T., Júnior, T. A. F. S., Soman, J. M., \& Maringoni, A. C. (2015). Chemical products induce resistance to Xanthomonas perforans in tomato. Brazilian Journal of Microbiology, 46, 701-706.

Khanna, K., Sharma, A., Ohri, P., Bhardwaj, R., Allah, E. F. A., Hashem, A., \& Ahmad, P. (2019). Impact of plant growth promoting rhizobacteria in the orchestration of Lycopersicon esculentum mill. Resistance to plant parasitic nematodes: A metabolomic approach to evaluate defense responses under field conditions. Biomolecules, 9, 4-30.

Limanska, N., Korotaeva, N., Biscola, V., Ivanystsia, T., Merlich, A., Franco, B. D. G. M., Chobert, J. M., Ivanytsia, V., \& Haertlé, T. (2015). Study of the Potential Application of Lactic Acid Bacteria in the Control of Infection Caused by Agrobacterium tumefaciens. Journal of Plant Pathology \& Microbiology, $06,1-13$.

Midha, S., \& Patil, P. B. (2014). Genomic Insights into the Evolutionary Origin of Xanthomonas axonopodispv. citri and Its Ecological Relatives. Appliedand Environmental Microbiology, 80, 6266-6279.

Modesto, G. L. A., Teixeira, S. A., Silveira, S. R. M., \& Almeida, T. M. M. (2016). Normas e Procedimentos de Segurança e Boas Práticas dos Laboratórios da Embrapa Agroindústria Tropical, Embrapa Agroindústria Tropical, 1-55.

Mohamed, A. H., Osman, G. Y., Zowail, M. E. M., \& Esawy, H. M. I. E. (2016). Effect of Lactobacillus sporogenes (probiotic) on certain parasitological and molecular aspects in Schistosoma mansoni infected mice. Journal of Parasitic Diseases, 40, 823-832.

Pandey, N., Malik, R. K., Kaushik, J. K., \& Singroha, G. (2013). Gassericin A: a circular bacteriocin produced by Lactic acid bacteria Lactobacillus gasseri. World Journal of Microbiology and Biotechnology, 29, 1977-1987.

Peixoto., R. A., Mariano, R. L. R., \& Viana, O. I. (2006). Meio semi-seletivo para isolamento de Xanthomonas campestris pv. Viticola, Ciência Rural, 36, $1317-1320$.

Prabhurajeshwar, C., \& Chandrakanth, K. R. (2017). Probiotic potential of Lactobacilli with antagonistic activity against pathogenic strains: An in vitro validation for the production of inhibitory substances, Biomedical Journal, 40, 270-283. 
Research, Society and Development, v. 11, n. 2, e28011225760, 2022

(CC BY 4.0) | ISSN 2525-3409 | DOI: http://dx.doi.org/10.33448/rsd-v11i2.25760

Rodrigues, A. A. (2009). Atividade antimicrobiana e produção de enzimas de interesse biotecnológico de bactérias isoladas de diferentes habitats. Dissertação (área de concentração em microbiologia) - Faculdade de Farmácia da Universidade Federal de Goiás, 2009.

Silva., A. G. D., Rocha, C. M., Carvalho, O. A., Fernandes, A. C. M., \& Carmo, F. G. M. (2006). Efeito de produtos químicos e biológicos sobre a mancha bacteriana, flora microbiana no filoplano e produtividade de pimentão. Horticultura Brasileira, 24, 1-7.

Teper, D., Girija, A. M., Bosis, E., Popov, G., Savidor, A., \& Sessa, G. (2018). The Xanthomonas euvesicatoria type III effector XopAU is a nactive protein kinase that manipulates plant MAP kinase signaling. PLoS pathogens, 14, 1-33.

Wang, Y., Sun, P., Li, H., Adhikari, B, P., \& Li, D. (2018). Rheological Behavior of Tomato Fiber Suspensions Produced by High Shear and High Pressure Homogenization and Their Application in Tomato Products. International Journal of Analytical Chemistry, 18, 1-12.

Zaluga, J., Stragier, P., Vaerenbergh, V. J., Maes, M., \& De vos, P. (2013). Multilocus variable-number-tandem-repeats analysis (MLVA) distinguishes a clonal complex of Clavibacter michiganensis subsp. michiganensis strains isolated from recent outbreaks of bacterial wilt and canker in Belgium. BMC microbiology, 13, 1-15. 